\title{
Social responsibility in professional accounting training
}

\section{Responsabilidad social en la formación profesional de contabilidad}

\author{
CUSIMAYTA-QUISPE, Magna Asiscla† \& DELGADO-PIZARRO, César Augusto
}

Universidad Andina del Cusco, Peru.

ID $1^{\text {st }}$ Author: Magna, Cusimayta-Quispe / ORC ID: 0000-0003-3994-1783

ID $1^{\text {st }}$ Co-author: César, Delgado-Pizarro / ORC ID: 0000-0001-5708-6210

DOI: $10.35429 /$ EJS.2021.14.8.1.7

Received: January 10, 2021; Accepted: June 30, 2021

\begin{abstract}
Social responsibility in the academic training of the public accountant within the framework of the fulfillment of the accountability roles of the State, the company and other organizations, to society; it is particularly relevant for peace and social cohesion. The study was carried out at the Professional Accounting School of the Andean University of Cusco - Perú (UAC) with a non-experimental qualitative approach, to facilitate the knowledge of the perception of accounting professionals regarding the exercise of their activity; the data collection technique was the survey and the semi-structured interview. The results show that the public accountant, in the performance of the work emphasizes efficiency; the valuation of his ethical principles; and, in the responsible contribution to the related areas within the organization; as well as incipiently to the preservation of natural resources for a healthy environment. It is concluded that in relation to social responsibility, the accounting professional contributes from their perspective in efficiency, transparency and in support to other areas of the organization and also, still tenuously, to the preservation of the environment.
\end{abstract}

Social responsibility, Public accountant, Accounting

\section{Resumen}

La responsabilidad social en la formación académica del contador público en el marco del cumplimiento de los roles de rendición de cuentas del Estado, la empresa y otras organizaciones, a la sociedad; es particularmente relevante para la paz y la cohesión social. El estudio se realizó en la Escuela Profesional de Contabilidad de la Universidad Andina del Cusco (UAC) con el enfoque cualitativo no experimental, para facilitar el conocimiento de la percepción de profesionales de contabilidad respecto al ejercicio de su actividad; la técnica de recolección de datos fue la encuesta y la entrevista semiestructurada. Los resultados muestran que el contador público, en el desempeño de la labor hace hincapié en la eficiencia; la valoración de sus principios éticos; y, en la contribución responsable a las áreas vinculadas dentro de la organización; así como incipientemente a la preservación de los recursos naturales para un ambiente saludable. Se concluye que en relación con la responsabilidad social el o la profesional en contabilidad, aporta desde su perspectiva en la eficiencia, la transparencia y en el apoyo a otras áreas de la organización y también, tenuemente todavía, a la preservación del ambiente.

Responsabilidad social, Contador público, Contabilidad

Citation: CUSIMAYTA-QUISPE, Magna Asiscla \& DELGADO-PIZARRO, César Augusto. Social responsibility in professional accounting training. ECORFAN Journal-Spain. 2021. 8-14:1-7.

$\dagger$ Researcher contributing as first author. 


\section{Introduction}

47 years ago, the practice of the public accountant profession focused on taxation, where accounting was carried out manually as an obligation with little control by the State. Companies often replaced him with the commercial accountant, since his signature was recognized as valid in accounting and tax processes. Many of the business organizations were looking for the accountant who would find a way to pay the least amount to the treasury.

In the current context, the exercise of the profession of public accountant is focused on tax obligations, where accounting is mechanized and online, it is mandatory and carried as an obligation with strong control by the State, particularly by the National Superintendency of Tax Administration - Sunat. Companies prefer the accountant, who punctually complies with tax obligations; They are deeply uncomfortable with non-compliance or knowing that they have been notified of debts or even fines.

This new market demand for goods and services generated changes in the training of those who chose to pursue a professional career as a public accountant. Like the introduction of learning in action, in so many years ago, the training was extremely theoretical, with a gap between what was taught in the classrooms and what was needed in the workplace in a context of increasing appropriation of new computer technologies. Although these new tools were procedurally favorable, it was not addressed yet from university education, how the daily work of the person specialized in accounting contributes to social change -understood this as the full fulfillment of people's rights- from access universal to the opportunities offered by the development of a territory with a democratic government immersed in a social market economy.

In Peru, the previous University Law, Law 23733 (December 17, 1983), considered as a fundamental role of the university the development of actions of social projection and university extension, as an educational proposal of promotion and cultural diffusion and professional studies specific that were extended in favor of those who were not regular students; in some occasions these were free and in others they led to a paid certification.
But, social responsibility, as such, was recently incorporated into the University Law, Law 30220 (July 9, 2014, article 124), where it is conceptualized as: The ethical and effective management of the impact generated by the university on society due to the exercise of their functions: academic, research and extension services and participation in national development (...); includes the management of the impact produced by the relations between the members of the university community, on the environment, and other interested organizations (...).

The Education Commission of the InterAmerican Accounting Association - CE AIC (2015), emphasizes social change, having to overcome, for this, the academic mechanical models, in favor of environmentally sustainable development, citizen participation and putting knowledge at the service of the human being.

The World Conference on Higher Education (CMES, 2009), Unesco, in response to the demands that redefine the mission and work of higher education institutions (IES), considered social responsibility as: "one of the pillars of the new world agenda for higher education to enhance its contribution to the eradication of poverty and sustainable development".

In this framework, an unsolved problem is the negative situation generated by the omission of responsibilities; the State that many times does not comply with rendering accounts to taxpayers about the destination and use of taxes despite the existence of the necessary technology; the taxpayer who does not make available to his clients the information on the payment of his taxes and the efficient and pertinent use of his resources in favor of the transparency and sustainability of the resources he uses; and society, while maintaining a weak organized participation to favor the fulfillment of their rights.

\section{Objective}

Determine the most relevant factors in the academic training of the public accountant in relation to social responsibility, within the framework of the fulfillment of the accountability roles of the State, the company and other organizations, to society. 


\section{Methodology}

According to the Consortium of Communication for Social Change (2008), a descriptive, nonexperimental qualitative approach was used that made it possible to measure the perception of directors, managers or owners of companies or entities about the performance of the accountant. public, in your organization. The study sample was non-probabilistic and intentional, which consisted of a group of 84 businessmen or company workers linked to the professional activities of public accountants.

The data collection technique was the survey and interview whose purpose was to obtain answers to the questions: How is the performance of the accountant or public accountant at work? What contribution do you value most from their work in your company or entity? How does their performance, in the work of the company, entity or organization, contribute to the community and their livelihood? The instrument for data collection used was the survey and interview form sent to the selected group via email and supplemented with open questions through calls via mobile phone.

\section{Results and Discussion}

Based on the surveys and interviews, the tabulation, processing and validation of the information collected from the 84 interviewees who are working in companies, entities, or who support the public accountant from a close environment were carried out; starting from the grouping of the initial response pre-categories from a performance perspective of the work of the public accountant, within the framework of social responsibility, supporting the analysis in the concepts that refer to cognition, procedures, attitude and experience in the context of continuous learning or "yachasun" as it is called in Quechua, the ancestral language of the Incas and widely used in the Andean territory of Peru.

Graphic 1 illustrates the results of the question: How is the performance of the accountant or public accountant at work? the efficient sub-category obtained $26 \%$, followed by responsibility with $18 \%$, timely management, $13 \%$ and, to a lesser extent, teamwork $3 \%$.

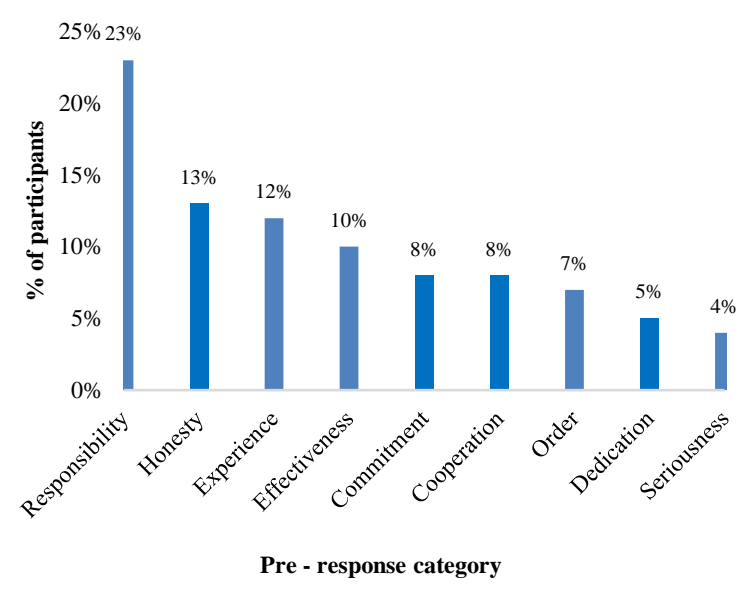

Graphic 1 Pre-response categories on the performance of the public accountant

Source: Own elaboration with data from the survey and interview

These response pre-categories show various attitudinal aspects that have a strong influence on the professional practice of the accountant or public accountant, in an intercultural context where the concepts of "munay", "llank'ay" and "yachay, which are rooted are rooted. However, little is addressed in academic training with clear orientations to the full fulfillment of the person, while for now the emphasis is on productivity criteria.

The answers to the question shown in Graphic 1 emphasize the "munay" whose meaning in Quechua expresses affection, affection and the will of the people towards a visit, friendship or family. So munaway, it is translated as love me; Munayki, how I love them and Munani Llactayta is, I love my people or community; more social responsibility in practice is expressed in the Ayni, which leads to reciprocity, collaboration and mutual cooperation.

The results show that the empathy and trust that are generated around the exercise of the profession, facilitate the understanding of the institutional or organizational purposes that precisely cause an impact on the population to which the university academic action contributes. The result of Graphic 1 focuses on the attitudinal pre-categories that comprise "the ways in which values are expressed in concrete situations and in the teleological horizon of human actions, that is, these are individual dispositions that allow reactions to other people" (Céspedes and Cossio, 2015).

In summary, the pre - response categories around the question, how is the performance of the accountant or public accountant at work? they were condensed, according to their intrinsic characteristics and intercultural connotation, into: experiential, attitudinal, procedural and cognition. 


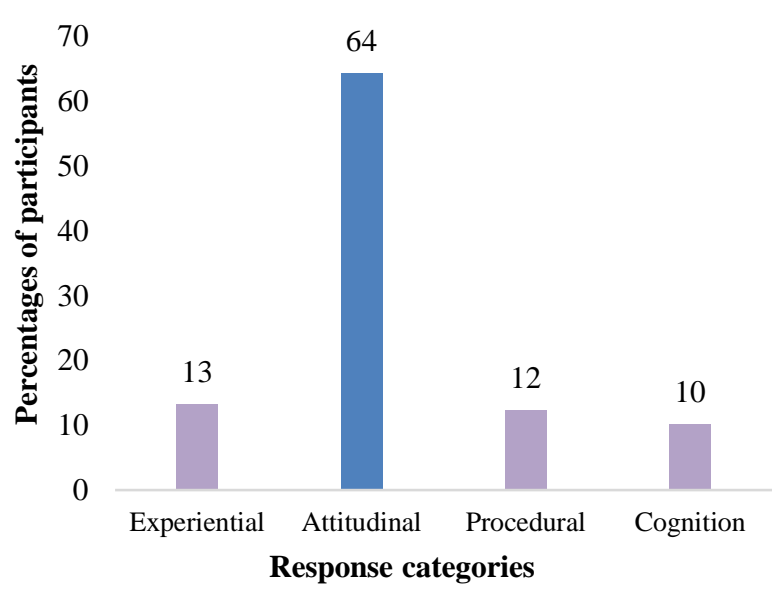

Graphic 2 Response categories on the performance of the public accountant

Source: Own elaboration with data from the survey and interview

Graphic 2 shows that $64 \%$ of those interviewed value in different ways, the attitudinal aspect of the public accountant in the performance of their professional work, however this factor is little worked on in the educational training curricula within the university; Although it has been incorporated as a component of the evaluation of social responsibility subjects, it does not have validated content and an effective contribution to its objective and even less aspects related to attitude in the performance of the professional function.

In Graphic 3 the results on the question are shown. What do you value more about the public accountant who is in the company or entity? Responsibility was valued with $23 \%$, honesty in $13 \%$, experience in $12 \%$ and humility with the lowest valuation with $3 \%$.

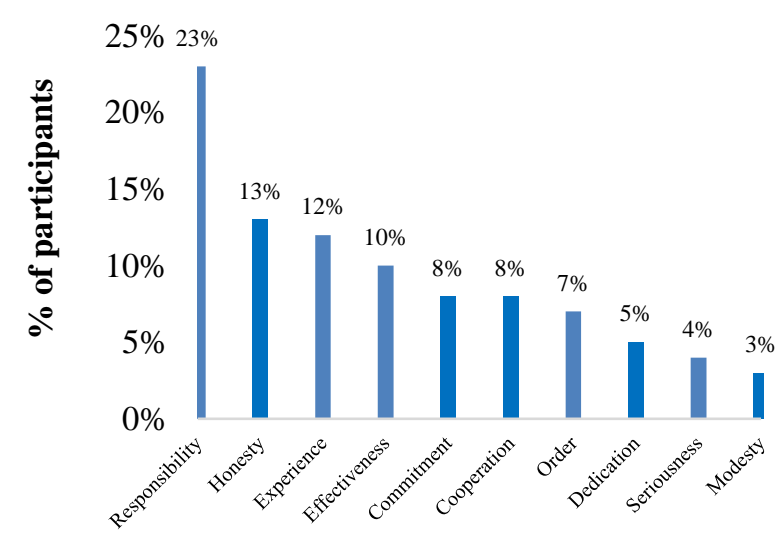

Pre - response categories

Graphic 3 Pre-response categories on what you value most of the public accountant

Source: Own elaboration with data from the survey and interview

In relation to Graphic 3, although the professional deontology course is incorporated into the curriculum of the professional accounting school; honesty, transparency and ethics are not evaluated in practice or in learning by doing to demonstrate attitudinal changes in the fulfillment of professional functions.
The answer to the question in Graphic 3 emphasizes the "yachay", it is a Quechua word, which includes much more than mere knowledge, as it refers to the promotion of knowledge, through sustainable actions that link knowledge with doing in favor of the community. Through the value of "yachay" knowledge, intergenerational transmission from father to son is practiced.

The results are focused on two categories; the procedural one that contains "the investigative abilities characteristic of science integrated by skills, a specific declarative knowledge of the subject and a way of reasoning in accordance with it, that is to say, reasoning skills" (Guisasola et al., 2003, p. 18) and cognition that "refers to the ability to assimilate and process data, assessing and systematizing the information accessed from experience, perception or other ways" (Layza, 2015).

In short, the pre - response categories around the question, what do you value most about the public accountant who is in the company or entity? They were condensed, according to their intrinsic characteristics, in experiential, attitudinal, procedural and cognition, obtaining the representation shown in Graphic 4.

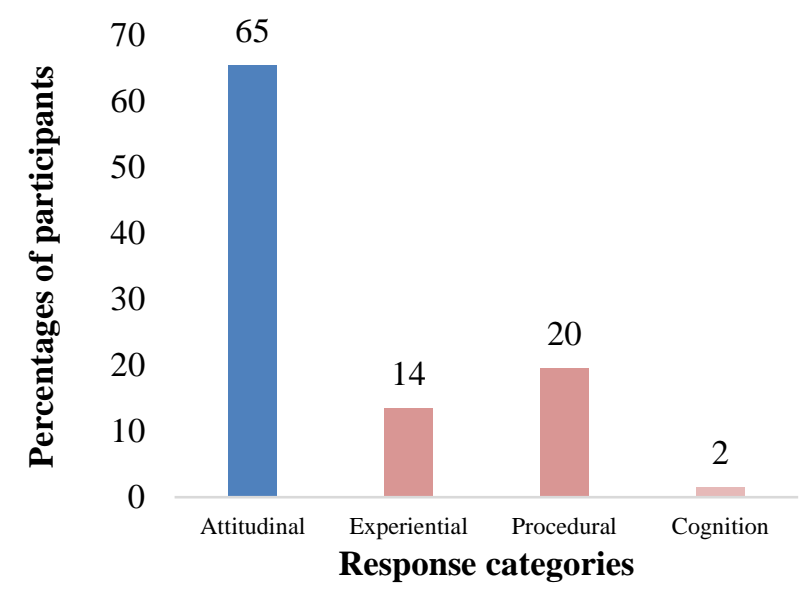

Graphic 4 Response categories on what you value most about the public accountant

Source: Own elaboration with data from the survey and interview

Again, the most valued in the professional performance of the accountant appears the attitudinal factor with $65 \%$, however they result with a relevant score, also the procedural factors and experience with 20 and $14 \%$ respectively. Graphic 5 shows the results of the question, how does your performance contribute, in the work of the company, entity or organization, towards the community and its livelihoods? The answers were: Support obtained $17 \%$, responsibility $14 \%$, knowledge $13 \%$, compliance with regulations $12 \%$ and with a lower percentage confidence with $2 \%$. 


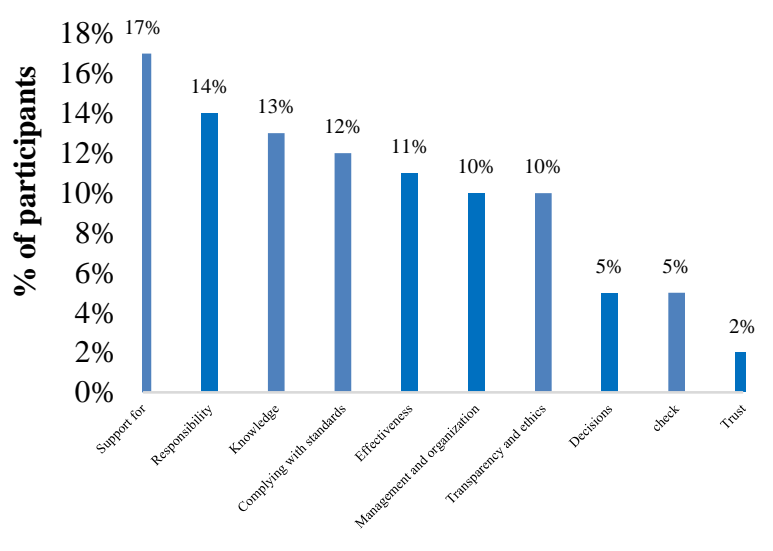

Pre - response categories

Graphic 5 Pre-response categories on the contribution of the public accountant's performance

Source: Own elaboration with data from the survey and interview

In Graphic 5, the support, responsibility and knowledge of accounting aspects and internal control of companies or organizations are highly valued by those who demand the professional service of the accountant.

The aspects valued emphasize the "llank'ay", it is a Quechua word, which means work with responsibility and knowledge, not necessarily in exchange for a monetary payment, but for support or solidarity.

The results emphasize the experiential category, defined as "the generation of a theory of action from one's own experience" (Tecnológico de Monterrey, 2010 cited in Galeano et al., 2018, p. 53). In addition, it is a method that "tries to develop people's ability to learn from their own experience, always within a specific and developed conceptual and operational framework" (International University of Valencia, 2018).

It is usual that students who show professional solvency, in addition to being specialized and having good relationship skills with change agents, express the message that the most useful thing in teaching-learning classes were the moments in which the teacher shared his experiences, with which he motivated each student to experience their own experience in the exercise of the profession.

In summary, the pre - response categories around the question, how does your performance, in the work of the company, entity or organization, contribute to the community and its livelihoods? they were condensed, according to their intrinsic characteristics, into experiential, attitudinal, procedural and cognition.

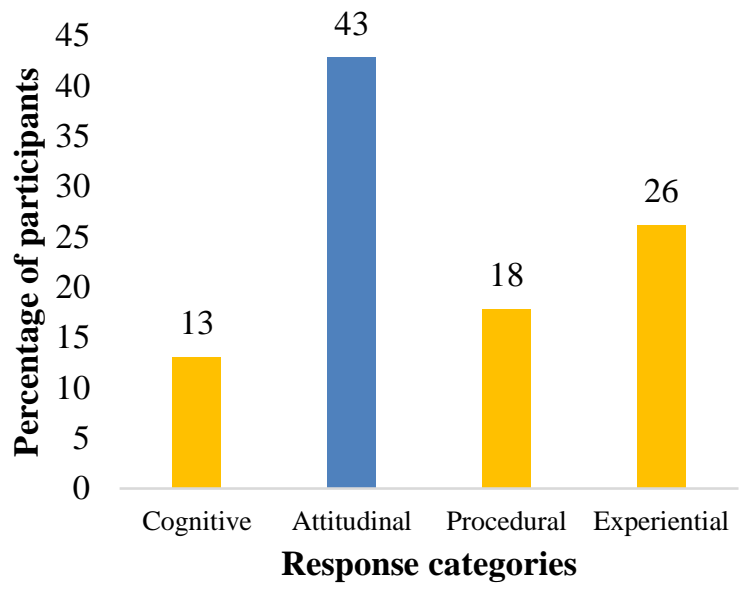

Graphic 6 Response categories on the contribution of the public accountant's performance

Source: Own elaboration with data from the survey and interview

Graphic 6 shows that the contribution of your performance, as a public accountant, in the work of the company, entity or organization, towards the community and its livelihoods continues to have a high valuation in the attitudinal factor with $43 \%$, but in this opportunity the experience, the handling of procedures and the cognitive aspect are much more recognized, with 26, 18 and $13 \%$ respectively.

Procedurally, regulatory modernization is required to obtain and register supporting supporting documents so that no further damage is caused to the environment by the excessive use of paper, storage spaces, filing cabinets and others that may very well be replaced by means less wicked to livelihoods and the environment in general.

In the field of audits, the costs of control, supervision and monitoring demanded by the supreme auditing entity of Peru, many times far exceed the benefits that they provide to society or users, given that the budgets for their operation and maintenance are extremely high. below those that are required, and even more are not assigned for their respective control.

In other words, the allocations claimed by the control entities are simply not feasible in economies where the urgency of having goods and services barely covers the amounts to acquire the assets, without being able to allocate additional sums for control expenses for compliance with the law. No. 27785 (El Peruano; art. 32, subsection i. 2002), which establishes the authority of the Comptroller General to request the documents that support the reports of the internal audit bodies or audit companies who are obliged to keep by a period of 10 supporting documents. 
It is urgent to replace these norms that decrease the value of the benefit - cost ratio, calling for actions that can be replaced by mechanisms of social accountability in strengthened contexts of decentralization and democratic participation.

In the analysis of the answers to the three questions, four categories were accumulated, which, organized by their relevance in the collective assessment, are: attitudinal, experiential, procedural and cognition; in the understanding that a transformation or change of behavior of a current situation is sought where the professional in accounting deals with the keeping of books, statements and surrenders to the Sunat, seeking that the tax collection is that provided by law; to another that links its actions with more emphasis on the contribution to social responsibility or Allin ruway, allin umachaq, in terms of accountability and transparency of the State or the company, towards society, with an intercultural perspective that recovers ancestral values of transparency and permanent dialogue with the community, in a scenario of preservation of the environment or livelihoods. See Graphic 7.

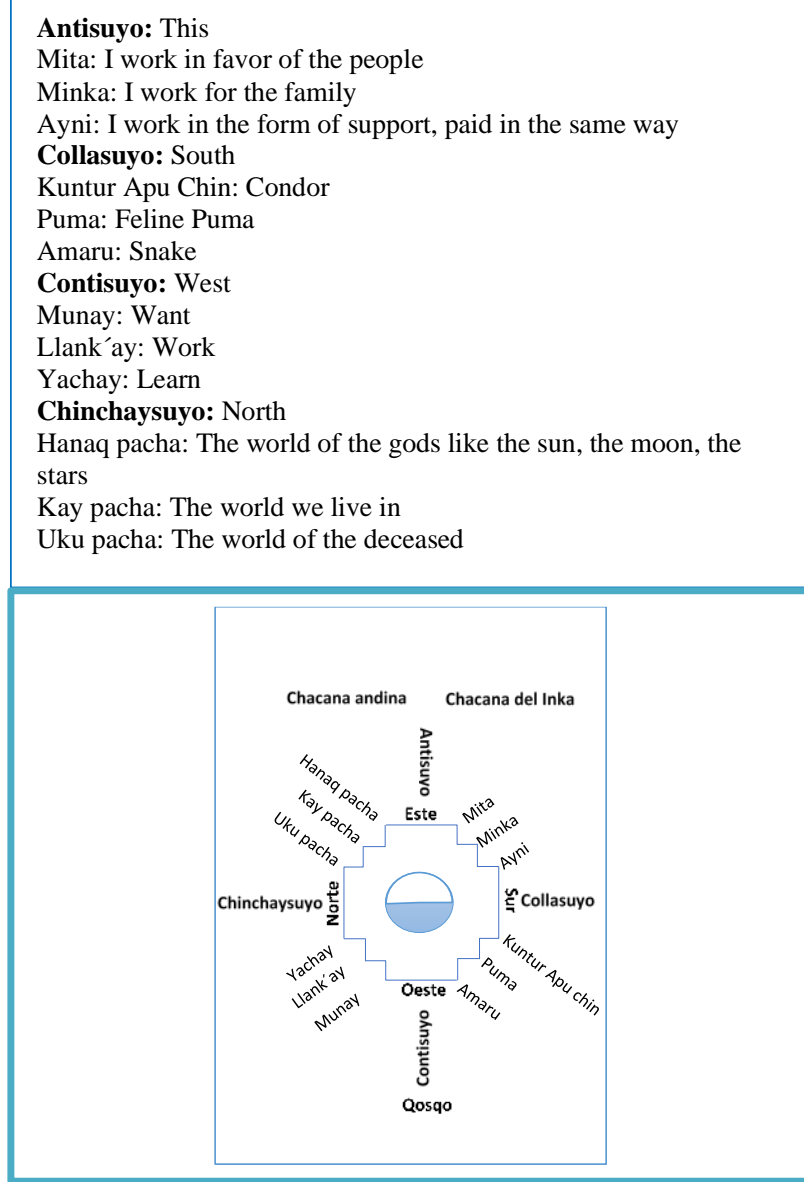

Graphic 7 Accountability intertwined in the ancestral coexistence of Cusco

Source: Appropriate from the digital magazine of Architecture - La Chakana

\section{Conclusions}

The educational model by competencies that is available at the university should serve as a basis to strengthen the attitudinal and experiential aspects in the learning process of each student, in their own environment of coexistence and their livelihoods.

Design a dialogue process where the attitudinal aspects of the accounting professional are evaluated, looking at the concrete reality in which your organization operates and identifying the results or scope as a product of their professional interaction in the work team.

The experience in the knowledge of the accounting aspects and the internal control of the companies or organizations, are highly valued by those who demand the professional service of the accountant or accountant. In general, they state that they end up familiarizing themselves first with her accounting and then with the objectives of the company or organization; while still weak, the implementation of accountability mechanisms or dialogue with the community to which the accounting professional ultimately contributes.

\section{References}

Bernal, T. y Mantilla, W. (2015). Investigación de procesos cognitivos en educación. Hallazgos, (1) $2 . \quad$ p. Available in:
https://doi.org/10.15332/s17943841.2004.0002.05

Carrera, X. (2002). Uso de diagramas de flujo y sus efectos en la enseñanza-aprendizaje de contenidos procedimentales. Área de tecnología (ESO) [Tesis de doctorado, Universitat de Lleida]. Repositori Obert UdL. Available in: https://repositori.udl.cat/handle/10459.1/63815

Cusimayta, M. (2019). La responsabilidad social en la auditoría: transparencia para la cohesión social. Universidad Andina del Cuzco. pp. 41-46

Céspedes, J. y Cossio, G. (2015). La enseñanza de los contenidos actitudinales de las ciencias sociales: un análisis desde las prácticas docentes [Tesis de licenciatura, Universidad de Antioquia]. Repositorio digital de la Universidad de Antioquia. Available in: http://ayura.udea.edu.co:8080/jspui/handle/123 456789/2078

Galeano, M.; Parra, C. y Chocontá, J. (2018). Educación ambiental en la primera infancia: una mirada en Latinoamérica. Universidad de la Sabana. p. 53. Available in: https://doi.org/10.5294/978-958-12-0484-7

CUSIMAYTA-QUISPE, Magna Asiscla \& DELGADOPIZARRO, César Augusto. Social responsibility in professional accounting training. ECORFAN JournalSpain. 2021 
Guisasola, J.; Furió, C.; Ceberio, M. y Zubimendi, J. (2003). ¿Es necesaria la enseñanza de contenidos procedimentales en cursos introductorios de física en la universidad? Enseñanzas de las Ciencias, número extra. p. 18. Available in: https://core.ac.uk/download/pdf/13268122.pdf

Hernández, D. (2010). Idea del Estado en Carl Schmitt aportes para una genealogía de lo político. Argumentos, 23(64). pp. 89-104. Available in: http://www.scielo.org.mx/scielo.php?script=sci _arttext\&pid=S0187-57952010000300005

Layza, F. (2015). Estrategias de enseñanza que desarrollan procesos cognitivos en el área de ciencia, tecnología y ambiente de los docentes del tercer grado de secundaria, UGEL 04, Trujillo [Tesis de maestría, Universidad Peruana Cayetano Heredia]. Dspace Repository. Available in: http://repositorio.upch.edu.pe/handle/upch/130

Ley 13253, Ley profesionalización de los contadores (September 11, 1959). Se reconoce la profesión universitaria de contador público. Available in: https://ccpl.com.pe/wpcontent/uploads/2020/08/2020-08-13-LEY-DEPROFESIONALIZACION.pdf

Ley 26300, Ley de los Derechos de Participación y Control Ciudadanos (May 3, 1994). artículo 3, literal c. Available in: https://www.web.onpe.gob.pe/modCompendio/ html/procesos_electorales/ley_derechos_partici control_ciudadano.html\#: :text=26592\%20y\% $2026670 \% 20$ y\%20restituye,de\%20Participaci\% C3\%B3n\%20y\%20Control\%20Ciudadanos.\&te $\mathrm{xt}=\mathrm{La} \% 20$ presente $\% 201$ ey\%20regula\%20el,de $\% 20$ conformidad\%20con\%201a\%20Constituci $\% \mathrm{C} 3 \% \mathrm{~B} 3 \mathrm{n}$.

Ley 27785, Ley orgánica del Sistema Nacional de Control y Contraloría General de la República, art. 32, inc. i. (July 23, 2002). Available in: http://doc.contraloria.gob.pe/documentos/TILO C_Ley27785.pdf

Ley 28951, Ley de actualización de la ley 13253 y creación del Colegio de Contadores Públicos (January 15, 2007). Segunda disposición complementaria. Available in: http://www.oas.org/juridico/spanish/mesicic3_p er_ley28951.pdf

Naciones Unidas (s. f.). Objetivos de desarrollo sostenible. Retrieved July 31, 2020 from: https://www.un.org/sustainabledevelopment/es/ objetivos-de-desarrollo-sostenible/
Otero, J. (Dir.) (2015). Estrés laboral y Burnout en profesores de enseñanza secundaria. Diaz de Santos. p. 19.

Romero, L.; Salinas, V.; Mortera y F. (2010). Estilos de aprendizaje basados en el modelo de Kolb en la educación virtual. Apertura; p. 2. Universidad de Guadalajara. México, 2010. Available in: https://www.redalyc.org/pdf/688/68820841007. pdf

Universidad Internacional de Valencia (21 de marzo de 2018). Definición y beneficios del aprendizaje experiencial. Available in: https://www.universidadviu.com/definicion-ybeneficios-del-aprendizaje-experiencial/

Universidad Andina del Cusco - UAC (2015). Plan estratégico Institucional 2012-2021. Available in: https://www.uandina.edu.pe/descargas/docume ntos/planificacion/PEI-2012-2021-UAC190216.pdf

Universidad Andina del Cusco - UAC (s. f.). Misión y visión contabilidad. Available in: https://www.uandina.edu.pe/index.php/misionvision-contabilidad/ 